\title{
A comparison of two ways of expressing the voluntary intake of oak foliage-based diets by goats raised on rangelands
}

\author{
M Meuret1, S Giger-Reverdin² \\ 1 INRA-SAD, Unité d'Ecodéveloppement, Domaine Saint-Paul, BP 91, 84143 Montfavet Cedex; \\ 2 INRA Station de Nutrition et Alimentation, 16, rue C-Bernard, 75231 Paris Cedex 05, France
}

\begin{abstract}
Introduction - The intake of fresh oak foliage by dairy goats raised on rangelands is being investigated in Provence (southern France). Voluntary dry matter (DM) intake is unexpectedly high and regular (Meuret, 1988). The aim of this study was to assess the applicability of prediction equations for voluntary intake, established for goats fed high-value nutritive diets, under the conditions in Provence rangelands.
\end{abstract}

Materials and Methods - Groups of 3 Rove breed goats, kidding at the end of January, were placed in digestibility cages, fitted for the distribution of whole tree branches (Meuret, 1988). The goats were either dried off and fed only foliage ad lib, or lactating and fed the same foliage ad lib with a nitrogen-rich supplement (at a rate of less than $15 \%$ total DM in the diet). Live oak (Quercus ilex) was tested 6 times in April (8\% crude protein (CP), $41 \%$ acid detergent fiber (ADF) of which $42 \%$ was lignified). White oak (Quercus pubescens) was tested twice in July ( $11 \%$ CP, $36 \%$ ADF of which $44 \%$ was lignified). Prediction equations tested are from Giger (1987).

Results and Discussion - Mean deviations between actual and predicted intakes are expressed as a multiple of the standard deviation (SD) of the prediction equations. The prediction linking voluntary DM intake (VDMI) with metabolic weight (MW) and fat-corrected milk yield (FCM) under- estimated the intake of foliage diets by 1.3 SD $(0.32 \mathrm{~kg} \mathrm{DM})$ for $Q$ ilex and by $3 \mathrm{SD}$ (0.74 $\mathrm{kg} \mathrm{DM})$ for $Q$ pubescens. Inclusion of diet organic matter digestibility (dOM) improved prediction values: $Q$ ilex VDMI was then overestimated by only $0.3 \mathrm{SD}$ ( $0.06 \mathrm{~kg} \mathrm{DM})$ but $Q$ pubescens VDMI was still underestimated by 2 SD $(0.42 \mathrm{~kg}$ DM). Using the prediction equation of voluntary digestible organic matter intake (VdOMI) with the same MW and FCM, the prediction for $Q$ ilex became highly satisfactory $( \pm 0.1 \mathrm{SD}= \pm 0.02 \mathrm{~kg} \mathrm{dOM})$; however, the $Q$ pubescens intake was still underestimated by $1.6 \mathrm{SD}(0.42 \mathrm{~kg} d \mathrm{OM})$.

Foliage-based diets can be voluntarily ingested by goats raised on wooded rangelands at higher levels than those of high quality diets for dairy goats, considering the VDMI (90-140 g VDMl/kg MW). When one takes dOM into account, these results are partially consistent with predictions for goats fed high-value nutritive diets $(45-75 \mathrm{~g} \mathrm{VdOMl} / \mathrm{kg} \mathrm{MW})$. These diets are poorly digestible (around 55\% dOM) but probably contain sufficient amounts of non-lignified portions which are rapidly degraded in the rumen.

Giger S (1987) Thèse de Docteur Ingénieur, INA-PG, Paris

Meuret M (1988) Small Ruminant Res 1, 273290 